\title{
TÜRKMEN YAZAR ÖVEZDURDU NEPESOV'UN “UZAK UZAK YILLAR” ROMANININ YAPI VE TEMA BAKIMINDAN INCELENMESi ${ }^{1}$
}

Yasin ÇAĞLAR*

\author{
Doç. Dr. Mehmet ÖZEREN**
}

\begin{abstract}
Öz
Çağdaş Türkmen Edebiyatı'nın en önemli şair ve yazarlarından biri olan Övezdurdu Nepesov birçok şiir, roman, hikâye ve tiyatro gibi eserler vererek Çağdaş Türkmen Edebiyatı'nın gelişmesinde önemli rol üstlenmiştir. Türk dünyası ile ilgili şimdiye kadar birçok çalışma yapılmıştır. Ancak Övezdurdu Nepesov'un Türkmenistan'da tanınmasının yanıda Türkiye'de yeterince bilinmemesi münasebetiyle böyle bir çalışma intiyacı hasıl olmuştur. Bu çalışma ele alınırken roman inceleme yöntemlerinin dışına çıkılmadan geniş bir perspektifle çözümleme yapılmıştır. Övezdurdu Nepesov bu romanla Türkmen sosyo-kültürel hayatına, tarihine ışık tutmuş ve modernist bir anlayışla Türkmen romanının gelişmesine katkıda bulunmuştur. Romanın başkarakteri olan İlaman'ın başınden geçen olaylar kronojik zaman dilimi içinde ele alınmıştır. Böylece zaman çizgisi roman karakterlerine ayak uydurarak tarihin akışı değiştirilmemiş, zaman ve mekan olduğu gibi kalmıştır. Övezdurdu Nepesov'un "Uzak Uzak Yıllar" adlı romanında Türkmen coğrafyasında 2. Dünya Savaşının getirdiği yosullaşmayla birlikte ahlaki çöküşün yansıması anlatıı. Problematik olaylar, romanın baş karakteri aracılığıyla duygusal epizotlar halinde karşımıza çıkar. Romanda toplumsal olayların sonucu olan trajik kırılmalara değinilerek romantik bir hava verilmiştir. Tematik kurgu yüklenirken şahıslar üzerindeki yansımalar dikkat edilip aksettirilmiş ve romantik yaklaşımlara ulaşıımışıır. Şahıslar mekanın dışında hareket etmeyerek tarihi vak'a zuhur etmiş. Böylece itibarî alem sanatsal görüngü halinde olay ve kişiler üzerindeki psikolojik unsurları seçebilme ayrımı elde edilmiştir. Son olarak roman bölümler halinde irdelenip bir çıkarım elde edilmiştir.
\end{abstract}

Anahtar Kelimeler: Türkmen Edebiyatı, Övezdurdu Nepesov, Yapı ve Tema

\section{EXAMINATION OF TURKMEN AUTHOR ÖVEZDURDU NEPESOV'S NOVEL NAMED AS} “UZAK UZAK YILLAR" IN THE TERMS OF STRUCTURE AND THEME

ABSTRACT

Övezdurdu Nepesov, one of the most important poets and writers of Contemporary Turkmen Literature, played an important role in the development of Contemporary Turkmen Literature by giving works such as many poems, novels, stories and plays. Many studies have been done about the Turkish world so far. However, the need for such a study arose due to the fact that Övezdurdu Nepesov was not known enough in Turkey as well as being known in Turkmenistan. While this study is being handled, an analysis has been made with a broad perspective without leaving the novel analysis methods. With this novel, Övezdurdu Nepesov shed light on the Turkmen socio-cultural life and history and contributed to the development of the Turkmen novel with a modernist understanding. The events that passed through the head of llaman, the protagonist of the novel, are discussed in a chronological time frame. Thus, the flow of history was not changed by keeping up with the timeline novel characters, and the time and

\footnotetext{
${ }^{1}$ Bu çalışma, Fırat Üniversitesi Sosyal Bilimler Enstitüsü Çağdaş Türk Lehçeleri ve Edebiyatları Anabilim Dalında yapılan "Türkmen Yazar Övezdurdu Nepesov'un "Uzak Uzak Yıllar" Romanının Yapı ve Tema Bakımından İncelenmesi" adlı yüksek lisans tezinden üretilmiştir.

* caglaryasin@hotmail.com, Orcıd ID: 0000-0002-3406-3646

** Fırat Üniversitesi/Insani ve Sosyal Bilimler Fakültesi/Çağdaş Türk Lehçeleri Ve Edebiyatları Bölümü, mehmetozeren@hotmail.com, Orcıd ID: 0000-0003-4386-8312
} 
place remained as they were. In Övezdurdu Nepesov's novel "The Far Far Years", the reflection of moral collapse along with the corruption brought on by the Second World War in the Turkmen geography is told. Problematic events appear as emotional episodes through the protagonist of the novel. In the novel, a romantic atmosphere is given by mentioning the tragic ruptures that are the result of social events. While loading the thematic fiction, the reflections on the people were carefully reflected and romantic approaches were reached. The persons did not act outside the place, thus making a historical event. Thus, the distinction of being able to select the psychological elements on events and people in the artistic phenomenon of the nominal world has been achieved. Finally, the novel was analyzed in sections and an inference was obtained.

Key Words: Turkmen Literature, Övezdurdu Nepesov, Structure and Theme GiRiş

Övezdurdu Nepesov'un Uzak Uzak Yıllar romanı 1980'li yılların Sovyet Türkmenistan'ında girdiği Cumhuriyet Yarışmasında üçüncülük ödülüne layık görülen bir kitaptır. Sosyalist gerçekçi bir duyuş tarzıyla kaleme alınan bu eserde İlaman karakteri üzerinden hem Türkmenlerin Sovyetler Birliği için II. Dünya Savaşı'na asker göndererek rejimine katkı sağlamak için var gücüyle çalıştıkları hem de toplumun ahlaki unsurları anlatır.

Övezdurdu Nepesov, roman kişilerini karakterize ederken toplumun tarihsel dinamiklerinden yola çıkarak kişilerin ruhsal yapısını somut bir yaklaşım içinde toplum normalarıyla bütünleştirmiştir. Böylece sosyalist gerçekçilik akımı romana hakim olarak edebî söylem içinde roman vücut bulmuştur. Bu söylemi roman inceleme yöntemleri bakımından şu şekilde irdeleyebiliriz:

\section{Eser İsim İçerik}

Bir edebî eserde isim ile içerik arasında ya doğrudan ya da dolaylı olarak bir ilişki söz konusudur. "Bu ilişki konu ve mesaj merkezli ironik, sembolik, imgesel bir tercihin sonucudur." (Eliuz 2014: 176) Çünkü yazar, eserin isminden hareketle okuyucuya bir mesaj verme amacı içinde olmuştur.

$\mathrm{Bu}$ roman ile ilgili yazarın bakış açısına bakılmaksızın sosyal gerçekçilik anlayışının hâkim olduğu Türkmen edebî sahasında oluşan yapıtlarda Sosvet Rusya'nın insanlar üzerindeki etkisini görmek mümkündür. Nitekim II. Dünya Savaşı'nın birey üzerindeki etkilerinden biri de yalnızlaşan bireyin dramıdır. Bu dram kimi eserlerde varlığını sürdürerek eserin ismi ile konusu arasında bir ilişki sürecinin başlamasına neden olmuştur.

İnsanın düşünce evreninde üretkenliğinin sonucu olan eserler vasıtasıyla yazar, kendi özünü ortaya koyacaktır. Tıpkı Uzak Uzak Yıllar romanında olduğu gibi önce eserin ismi zihinlerde birtakım kavramlar oluşmasına yardım edecek, sonra konu bütünlüğüne geçilecektir. Böylece Övezdurdu Nepesov'un Uzak Uzak Yıllar romanında eserin ismi ile içeriği arasında örtüşen bir yapı söz konusudur. Dolayısıyla Nepesov'un bu eserine seçtiği isim ile konu birbirini tamamlamakta, isim ile içerik vazgeçilmez bir unsur olarak romanın yapı taşını oluşturmaktadır. 


\section{Olay Örgüsü}

Uzak Uzak Yıllar romanı, "Ön Deyiş, 3 Bölüm, Söz Sonu Yerine ve Son Söz" olarak bölümlere ayrılıp yazar tarafından kaleme alınmıştır. Her bölüm kendi içinde numaralandırı ımıs ve bu numaralandırılan kısımlar da kendi içinde anlatım gruplarına ayrılmıştır. Romanı, içerik sırasını oluşturan bölümlere göre incelersek:

\section{Ön Deyiş (5-7 s.)}

II. Dünya Savaşı sürerken Ukrayna topraklarında Kerven Aga'yı kaybeden Gurban Çarı, savaş bittiğinde Kerven Aga'nın ölüm haberini İlaman'a iletir. Bu haberden sonra İlaman'ın teyzesi, onu Aşkabat'a götürür.

İlaman, Aşkabat'ta FZO'da eğitim aldıktan sonra tam otuz beş yıl boyunca demir yolu istasyonunda çalışır.

- Köyünün hasretiyle yanıp tutuşan İlaman, teyzesinin telkiniyle köyün yolunu tutar.

\section{Birinci Bölüm (8-54 s.)}

- $\quad$ Birgün Kerven Aga, Durdı Yasavul ile tohum almak için tren istasyonuna gider. Burada Kerim Bay adında birinin Sibirya'ya sürgüne gönderilmesi üzerine kızı Sona'yı Kerven Aga'ya emanet eder. Zaman içinde Sona ile evlenir. Ancak zengin birinin kızıyla evlendiği için Akçeşme'den çıkıp Çınarlı'ya göç etmek zorunda kalır. Çınarlı'ya geldikleri yıl İlaman dünyaya gelir.

İlaman, okul çağına geldiğinde okula gönderilir. Ancak bu sırada II. Dünya Savaşı çıkmış ve Türkmenistan, Sovyetler Birliği'nin bir parçası olduğu için savaşa katılır.

Askere gönderilenler arasında Goçaklı da vardır. Goçaklı, eşi Ene'yi Kerven Aga'ya emanet ettikten sonra birliğine katılır.

- $\quad$ Cephe gerisindeki köylüler ise kolhozdaki işleri yürütüp harman yerinde çalışmaya koyulurlar.

Harmandaki işleri yürüten İlaman, Akga Brigadir'in anlamsız hakaretlerine göğüs germek zorunda kalır. Bu durumu gören Ene ise sesini çıkarmadan içten içe Akga Brigadir'den memnun olmaya başlar.

Ene ile İlaman yan yana çalışması Akga Brigadir'in hoşuna gitmez ve İlaman'a başka görevler vererek Ene'den uzaklaştırmaya çalışır. Böylece Ene ile arasındaki duygusal bağını sürdürmek ister.

- Birgün Ene ile Akga Brigadir'in yakınlaşmasını gören İlaman gözlerine inanamayarak oracıkta bayılır. Doktor Arzu hemen yetişir ve müdahale eder.

Sonbaharın gelmesiyle Harman işleri azalmaya başlar. Böyle günlerin birinde Ene'nin annesi Meretgül, Ene'nin yanında kalmak için köye gelir.

- Günler hızlı bir şekilde ilerler. Ene ile Akga Brigadir'in yakınlaşmasından haberdar olan Kerven Aga, Akga Brigadir ile tartışma yaşar.

Aralık ayı olduğunda birgün kolhoz başkanı Anna, Kerven Aga'nın da askere gitmesi gerektiğini belirtir. Bu haberden sonra Kerven Aga, cepheye gitmek zorunda kalır. Gitmeden önce İlaman'a karısından kalan broş takıyı verir. 
Eşini askere gönderen Sülgün ise ekonomik sorunlar nedeniyle kızları Aysoltan ile Nursoltan'ı beslemekte zorlanır. Fakirlik yüzünden kızlarının hastalanmasına engel olamaz.

- $\quad$ Bir gün köye Doktor Arzu'nun oğlu Serdar'ın savaşta öldüğü haberi gelir. Doktor Arzu bu haber üzerine yıkılır.

- Köyde o yıl kışın soğuk yüzü daha derinden hissedilir. Böyle günlerin birinde Akga Brigadir, Üzümgül'e yaklaşmak ister. Ancak Üzümgül'den beklemediği bir tepki alınca oradan ayrılır.

İlaman babasını askere gönderdikten aylar sonra bir gün babasından mektup gelir. Mektubu Kerven Aga'nın ağzından Gurban Çarı kaleme almıştır. İlaman tarafından büyük bir memnuniyetle karşılanır.

İlaman için babasının mektubundan duyduğu sevinç çok kısa sürer. Sülgün'ün kızı Nursoltan'ın hastalığı ve ardından vefatı onu derinden sarsar.

\section{İkinci Bölüm (55-108 s.)}

- 1942 yılının yaz mevsimi geldiğinde savaş ile ilgili malumatları gazetelerden ve mektuplardan alınır. Bu haberlerde Almanların bozguna uğradığı anlatılır.

Köyde işler daha da artar. Böyle günlerin birinde kolhoz işleri ile ilgilenen İlaman'a Hudayberdi adında bir çcuk musallat olur ve İlaman'ı yere çalar. Hemen Sapargül gelir, Hudayberdi'yi azarlar. Ona gücünü kürek kullanarak göstermesini ister.

- Daha sonraları İlaman ile Hudayberdi sıkı dost olurlar. Hudayberdi, İlaman'a Oğulteç'i göstererek sevgilisi olduğunu söyler. Bir süre sonra Akga Brigadir gelerek İlaman'a bir kamçı yapıştırır. Bunu gören Hudayberdi hemen eline bir taş alarak Akga Brigadir'in kafasını kırar. Neye uğradığını şaşıran Akga Bridadir oradan uzaklaşır.

İlaman, bir tarafta kolhozda çalışırken bir tarafta ise Sülgün'e yardım etmek ister. Yoksulluktan zayıf düşen Sülgün ve Aysoltan'ın haline çok üzülür. Onlara yiyecek yardımında bulunur.

İlaman, bir gün Ene ile Akga Brigadir'i bir çukurluk yerde sarmaş dolaş halde görür. Bu durumdan çok utanır.

Akga Brigadir'in İlaman'ı dövmesini duyan kolhoz başkanı Anna, Akga Brigadir'i sürgüne göndermekle tehdit eder.

Yaz mevsiminin sonlarına doğru elde edilen hasadı taşımak için kolhoz başkanı Anna tarafından bir toplantı yapılır. Toplantıda Hudayberdi bu hasadı eşeklerle taşımak için kendisine bir şans verilmesini ister. Başta bu öneriye sıcak bakmayan Anna, sonra fikrini değiştirerek Hudayberdi'ye bir şans verir.

Günler geçtikçe yeni ölüm haberleri de gelmeye başlar. Durdı Muhafız, Muratı ile Atabay Orazmemmet'in şehadet haberini kolhoz başkanı Anna'ya iletir. Köy halkı bu haberden sonra ümitleri kırılır.

- $\quad$ Illaman ile sıkı dost olan Hudayberdi, gönüllü olarak askere gitmek istediğini İlaman'a belirtir. Bu duruma çok şaşıran İlaman, birkaç gün sonra Hudayberdi'nin askere gittiğini öğrendikten sonra çok üzülür.

Birgün Ene'nin annesi Meretgül evinde ziyafet verip köydeki herkesi çağıırr. Yemekten önce Oraz Şıh konuşma yaparak sürekli hükümeti eleştirir.

- $\quad$ İlaman, ziyafetten döndükten sonra evine kolhoz başkanı Anna ile Durdı Muhafız gelerek Oraz Şıh'ın Sovyet düşmanı olduğunu söyler. İlaman'ı da Oraz Şıh'ı takip etmekle görevlendirir. 
- $\quad$ Oraz Şıhın aslında İlaman'ın evinde gömülü olan altınları alıp kaçmak ister. Bu emeli için çok çalışır.

- $\quad$ Meretgül'ün tek arzusu Ene'nin Akga Brigadir ile evlenmesi olmuş; ancak Ene kocası Goçaklı'nın askerde olması Akga Brigadir ile ilişkisinin doğru olmadığını annesine söylemesi üzerine bir tartışma yaşanır.

Anna tarafından Oraz Şıh'ın göz önünde bulunması için ona bir görev verilerek İlaman'ı yanına yardımcı olarak tayin eder.

- Illaman, dağ tarafındaki harmanda çalıştığı bir gün Oraz Şıh, İlaman'ın evini kazar. İlaman evine dödüğünde bu duruma anlam veremez.

- $\quad$ İlaman, okulun buğday dolu olan sınıfında geceyi geçirmek için uyuduğu sırada Akga Brigadir ile Oraz Şıh'ın gelip kendi arasında konuştuğuna şahit olur. Bu konuşmada Oraz Şıh'ın Rusları eleştirerek kim güçlü olursa onun tarafında olduğunu anlatır.

- $\quad$ Illaman, Sülgün için biraz buğday almak amacıyla eve geldiğinde Oraz Şıh'ın evin içinde kazı yaptığını görür. Oraz Şıh tedirgin olup oradan kaçar. Ancak o akşam okulda İlaman'ı gördüğünde zor günler için evde buğday saklamak istediğini söyleyerek İlaman'ı inandırmak ister.

1942 yılının ekim ayında oğlu Serdar'ın ölümü ile derin acılar çeken Doktor Arzu'nun vefatı ile Çınarlı köyüne hüzün düşer.

\section{Üçüncü Bölüm (109-151 s.)}

- 1943 yılının mayıs ayı geldiğinde köye savaşta dönen birinin haberi gelir. Ene, bu kişinin kocası Goçaklı olduğunu düşünerek Akga Brigadir ile olan ilişkisinden dolayı pişmanlık duyar.

Kolhoz başkanı Anna'nın askere gitmesi üzerine Akga Brigadir kendini kolhoz başkanı olarak görür. Ancak bu girişimin yalan olduğu bir sürese sonra ilçeden gelen vekil üzerine ortaya çıktığında yeni kolhoz başkanı Durdı Muhafız olarak seçilir.

- $\quad$ Birkaç ay sonra Anna, savaştan döner ve yeniden kolhozun başına geçer.

- $\quad$ Akga Brigadir, Oraz Şıh'la Ene arasındaki ilişkiyi köy halkına anlattığı için tartışır. Ancak Oraz Şın bu suçlamayı kabul etmez.

Kolhoz başkanı Anna, Oraz Şıı'ın İlaman'ın evinde kazı yaptığını öğrendiğinde ilçe merkezindeki milis komutanı Atayıf'tan yardım alarak Oraz Şıh'ı yakalatmak ister.

- IIlaman Durdı Muhafız ile birlikte Oraz Şıh'ı takip ettikleri sırada İlaman'ın evine girdiğini ve bu sırada takip edildiğini anladığında hemen o anda Durdı Muhafız'ı öldürüp kaçar. Bir süre sonra Atayıf'ın emrindeki askerler Oraz Şıh'ı yakalar.

- $\quad$ İlaman'ın Oraz Şıh'ı yakalatmak için göstermiş olduğu cesaretten dolayı Anna ile Atayıf tarafından İlaman'a komsomol ünvanı verilir.

$\mathrm{Bu}$ olaydan sonra Atayıf'ın emri üzerine İlaman'ın evi askerler tarafından kazılarak içinde altın olan testi çıkartııı. Bu testinin içinden İlaman'a annesinden kalan yakut broşun bir parçası çıkartılarak İlaman'a teslim edilir.

Yakut broşu gören Üzümgül bu broşun kardeşi Sona'ya ait olduğunu hemen hatırladıktan sonra İlaman'ın aslında öz yeğeni olduğunu anlar.

- $\quad$ Olayla ilgili olarak Ene'ye ve Akga Brigadir'e hapis cezası verilir.

- $\quad$ İlaman, kendisi için üzücü olan bütün olaylardan sonra babasından bir mektup geldiğini gördükten sonra biraz ferahlar. 


\section{Söz Sonu Yerine (152-156 s.)}

- 1945 yılının baharı geldiğinde savaşın bitmesini isteyen köylülerde bir bıkkınlık görülür.

Bir gün evine giden İlaman karşısında Ene'yi görür. Ene çok pişman olduğunu ve artık Goçaklı'nın yüzüne bakamayacağını İlaman'a anlattıktan sonra oradan çıkıp gider.

- $\quad$ İlaman, Ene ile karşılaştıkları o geceden 5 gün sonra bir arabanın içinde Ene'nin cesedini görür.

- $\quad$ Ene'yi defnettikten sonraki gün Sabır Aga tarafından savaşın bittiği haberi gelir. Bu haber üzerine köylüler çok mutlu olurlar. Köyde eğlence düzenlenir.

\section{Son Söz (157-159 s.)}

- $\quad$ İlaman, savaş bittikten sonra teyzesi Üzümgül ile birlikte gittiği Aşkabat'a yerleşir. Otuş beş yıl Aşkabat'ta kaldıktan sonra köyüne döner.

- $\quad$ Köye döndüğünde ilk işi amcası Goçaklı'yı görür. Goçaklı savaştan döndükten sonra Oğulteç ile evlenir. İlaman, Oğulteç’i gördüğünde çok şaşırır.

Bir müddet sonra kalkıp Sülgün'ü görmek ister. Ancak Sülgün'ü akli yetilerini kaybetmiş bir şekilde görünce kendini ona göstermez ve sadece Sülgün'ün türkü söylemesini dinlemekle yetinir.

\section{Anlatıcı ve Bakış Açısı}

Anlatmaya bağlı edebî metinlerde tema ve yapı unsurlarının her biri roman oluşumunda rol oynar. Bu unsurlar eserin zaman, mekan ve kişilerin belirlemesi bakımından önem arz eder. Edebî metinlerde eserin muhteviyatı kadar itibarî unsurların yaratılmasında bakış açısının büyük bir etkisi vardır. Yazar her ne kadar gerçek dünyanın bir parçası olmuşsa, eser de itibarî alemin bir yansıması olarak oluşturulmuştur.

Yazar, eserini ortaya çıkarırken kimi zaman sözü kendisi söyler ve hiç kimseye fırsat vermeden eseri kendisi anlatır. Kimi zaman da yazar, sözünü itibarî bir varlık olan eserdeki bir kişiye verebilir. Böylece yapıttaki kişi, yazar adına konuşarak eser hakkında bilgi verir.

Uzak Uzak Yıllar romanı, anlatıcı ve bakış açısı yönünden irdelendiğinde roman genelinde hakim bakış açısı tekniği ile kaleme alınmıştır. Romanda yazar-anlatıcı, sözünü kendisi söylemiş ve hiç kimseye ihtiyaç duymadan olay örgüsünü anlatma yoluna gitmiştir;

"llaman ganatsyz uçýardy. Onuň ýüregi indi ençeme aý bäri ilkinji gezek şeýle ersdi. Onuň kakasyna bolan minnetdarlygynyn̆ möçberini ölçäp boljak däldi. Ýok beýle bagt ynsanda az-az bolýardy." （Nepesow 1986: 29)

(İlaman, sanki kanatları olmadan uçuyordu. Şimdi onun yüreği birkaç aydan beri ikinci defa farklı hissediyordu. Babasına olan minnettarlığının tarifi ölçülecek gibi değildi. Böyle zamanlar insanda çok az oluyordu.) 
Yazar tarafından olayların merkezindeki İlaman, vak'a zinciri içinde bir erkek karakter olarak okuyucuya sunulurken İlaman'ın yaşamı, eğitimi ve ahlakî duruşu bir proto-tip olarak yansıtılması gereği duyulmuştur. Nitekim Nepesov, yazar-anlatıcı tekniğiyle İlaman'ın yaşadığı bütün duyguları içtenlikle hissetmiş ve bunu anlatıcı olarak gözler önüne sermiştir;

"Oglan üçin kakasynyň aýdýan sözleri ýöne bir gürrüň bolman, ene hakdaky hüwdüdi. Oglan onuň süýjüliginden meýmireýärdi. Ol mähriban ejesi barada köpräk eşitmek isleýärdi." (Nepesow 1986: 9)

(Oğlu için babasının söylediği sözler bir konuşmadan ibaret değildi. Konuşulanlar annesi hakkında sanki bir ninniydi. Oğlu onun tatıı̆ı̆ından uyukluyordu. İlaman, sevgili annesi hakkında çok şey işitmek istiyordu.)

Nepesov, post-modern romancıların aksine olay örgüsünü dar zaman dilimi içinde vermeden geniş bir zamana yayarak anlatmıştır. Yazar-anlatıcı olarak şahısların duygu ve düşüncelerine önem vermiş ve kişileri yer yer konuşturarak monotonluğu kırma eğilimi göstermiştir;

Romanda yoğun olarak hakim bakış açısı yani yazar-anlatıcı olarak anlatma tekniği hüküm sürerken kahraman bakış açısının da romana dahil olduğu görülmektedir. Romanın prolog ve epilog bölümlerinde yazar, sözünü İlaman'a emanet ederek onun ağzından olaylar aktarılır. Böylece romanın başı ve sonu arasında bir bağ kurularak vak'a zinciri daha canlı ve objektif bir hâl almıştır. Bu bölümlerde İlaman karakteri vak'aları okuyucuya kendisi anlatır;

"Menem özbaşyma ýylgyrýardym. Dogrymy diýsem, penjirä garap, ýolagçylardan çekinip ýylgyrýardym. Nämä ýylgyrýanymy özümem duýamokdym. Diňe gursagmyň şatlykdan dolup-daşanyny duýýardym." (Nepesow 1986: 5)

(Ben de kendi kendime gülüyordum. Doğrusunu söylemek gerekirse pencereye bakıp yolculardan çekine çekine gülüyordum. Neye güldüğümü kendim de bilmiyordum. Ancak göğsümün mutluluktan dolup taştığını hissediyordum.)

Romanda İlaman, aykırı davranışlar sergilemekten kaçınarak ucuz insan, basit insan tiplemelerine girmez. Yazar İlaman'a sözünü emanet ederek aslında ideal insan tiplemesini de ortaya koymuştur.

\section{Olay Zamanı}

Edebî metinler için zaman kavramı büyük bir önem taşır. Anlatılan olayın okuyucunun nazarında önemli bir intiba bırakması için zaman kavramının olay örgüsüyle bir bütün olarak ele alınması gerekir. Nitekim edebî metinler bir unsuru olan romanlarda, şahıslar olayı yaşarken aynı anda zamanı da tüketme eğiliminde olurlar. Romanın başkarakteri olan İlaman'ın -öndeyiş bölümü hariç- küçük yaşta birçok zor şarta göğüs gererek önemli bir konuma gelmesi, zaman içinde vuku bulan bir olaydır. Önce annesini, sonra da babasını savaşta kaybetmesi ve akabinde gelen diğer olaylar kronolojik zaman dilimi içinde gerçekleşen olaylardır. Yazar, kimi zaman kalemini İlaman'a ve diğer karakterlere emanet ederek olayların gelişim çizgisini zaman içinde sürdürmüştür. Şahıslar ise zamanı bu süreç içinde tüketme eğilimi içinde olmuştur. 
"Zamanın ilk boyutu, hikâyedeki kahramanların ve anlatılan olayların gelişip büyümelerini, herhangi bir aksiyon içine girmelerini sağlayan sürekli, değişen ve dinamik bir yapı özelliği gösterir. Ne var ki, anlatıcının mizacı, bakış açısı ve hikâyedeki tematik unsurlar, zamanın algılanışı ve anlatım konusunda bazı değişikliklere sebep olurlar." (Çonoğlu 2001: 244). Anlatıcı kimi zaman anlattığı olayın gerçekçi bir hâl almak istemesinden ötürü geriye doğru zaman sıçramaları yapabilmekte ve olay örgüsünü daha da güçlendirmektedir. Uzak Uzak Yıllar romanında özellikle geriye doğru zaman sıçramaları üçüncü bölümde görmek mümkündür. Ancak bu sıçramalar olay örgüsünün yapısını bozmadan olaylar ve kişiler üzerinden kronolojik zamanın dışına çıkılmadan yapılmıştır. Yazarın olayları daha güçlü anlamda bilmesi adına yapıldığı fikri uyandırmaktadır.

Eserde zaman kavramı öndeyiş bölümü hariç, kronolojik olarak devam etmesi, şahısların anı yaşaması ile ilgili bilgi vermektedir. Çünkü olay akışı bir sırayı takip eder gibi dizilmiştir.

Vaka zamanını üç ayrı bölüme ayırmak mümkün olacaktır. Böylece 1941 yılından önce yani II. Dünya Savaşı'nın başlamasından önceki dönem, savaş dönemi ile toplumsal yaşam ve savaştan sonraki dönem olarak belirtilmiştir. Eserin büyük kısmı savaş dönemi içinde vuku bulan olay örgüsünü konu almıştır. Roman karakterlerinin bedeni ve ruhsal gelişimi bu sürece denk gelmekle birlikte birçok karakter bu savaş dönemi içinde hayatını kaybetmiştir.

Uzak Uzak Yıllar romanının yazarı Övezdurdu Nepesov, her ne kadar II. Dünya Savaşı'ndan sonra doğmuş olsa bile eserin arka plan kültürünü toplumsal açıdan iyi analiz etmiştir. O dönemi yaşamamasına rağmen itibarî bir âlem oluşturarak Türkmen tarihini romana aksettirmeyi başarabilmiştir.

\section{Olayın Geçtiği Mekân}

Övezdurdu Nepesov'un Uzak Uzak Yıllar romanında mekân kavramı ile vakanın geçtiği zaman akışında realist bir yapı oluşturmak istenmiştir. Kişilere bu mekânlar içinde varlığını ortaya koymak için vazifeler verilmiştir. Yazar, roman karakterlerinin yaşadığı mekânlarda bağlı bulunan siyasî düzenin bir yansıması olarak karakterlerin ruh hâllerine etkide bulunmuştur.

Genel olarak romana bakıldığında yazar tarafından vakanın zuhur ettiği mekânın dar bir çerçevede işlendiği görülmektedir. Zaman zaman başka mekânlara atıfta bulunulsa da olaylar belli yerlerde geçmektedir.

"Mekân romanda öncelikle sahne görevi görür." (Şengül 2010: 532). Bu sahne roman kahramanlarının olayın akışı içinde hareket etmesine olanak sağlar. Mekân ile birlikte daha somut adımlar atılarak başkahraman olan İlaman'ın hayatı somutlaştırılmıştır. Mekân, itibarî bir durumdan çıkartııı gerçek bir forma sokulmak istenmiştir.

Uzak Uzak Yıllar romanında mekânlar kimi zaman tasvirlerle açıklığa kavuşmuştur. Yazar bunu yaparken okuyucuya itibarî mekânı aksettirmiş ve orada yaşatmayı sağlamıştır. 
"Ayrıca mekânla eserde nakledilen vaka zinciri arasındaki münasebeti gözden uzak tutamayız." (Aktaş 2005: 127). Çünkü romanda gerçekleşen olaylar mekâna bağlı olarak gerçekleşmiş ve karakterler ise bu doğrultuda varlığını sürdürmüştür.

Romanın mekân unsuruna bakmak gerekirse dış ve iç mekân olarak ayırabiliriz. Bunlar:

\subsection{Eser Dış Mekânı}

Uzak Uzak Yıllar romanında dış mekân unsuru, eserde ön plana çıkmaktadır. Bu dış mekân ise Çınarlı köyüdür. Aslî ve değişmez bir mekân olarak seçilmiştir. "Bu mekân aynı zamanda romandaki vatan anlayışı, millî şuur, toprak vatan gibi ana temaların da sembolüdür." (Çonoğlu 2001: 257) Vatanın ve toprağın önemini vurgulayarak millî bilincin güçlenmesi sağlanmıştır. Roman karakterleri savaşın çıkışı ile vatanlarını korumak için ve savaş gerisindekileri mağdur etmemek için çaba sarf etmektedirler.

Romanda çok az da olsa Çınarlı köyünün tasviri yapılarak eserdeki ana mekânın vurgusu yapılmıştır. Romanın öndeyiş kısmında İlaman'ın köyün özlemiyle yanıp tutuşması açıkça dile getirilmektedir. İlaman için Çınarlı köyü bir yurt, bir vatan olmuş ve cennetini arzulayan biri gibi köye bakmaktadır.

Çınarlı köyü, her ne kadar İlaman'ın nazarında idealize edilse de bu köy büyük çatışmaların tezahürü olan bir yer olarak düşünülmektedir. Yazar romanda Çınarlı köyünü tasvir ederek roman kahramanlarının bir bütün içinde çatışma ve rekabetin yuvası olmasını sağlayacaktır. Böylece olay örgüsü sürecinde kendine bir takım olaylara gebe bırakacaktır.

Eserde diğer mekânların varlığına salık verilse de asıl olay Çınarlı'da geçer. İlaman'ın babası Kerven Aga, Sona ile evlendikten sonra Akçeşme'de tutunamayınca Çınarlı köyüne göç eder. Geldikleri yıl İlaman doğar. Böylece roman açısından Çınarlı köyünde serüvenler başlamaya hazır hale gelir.

Eserin dış mekânı olan Çınarı Köyü, Övezdurdu Nepesov tarafından itibarî olarak seçilmiştir. Türkmanistan'ın siyasî haritasında yeri bile olamayan bu mekân 1940'ı yılların Türkmenistan'ına bağdaştırılarak sosyokültürel yapısı hakkında bilgi vermektedir.

Romanda Çınarlı bir dağın eteklerinde kurulmuş ve etrafı çöl kumları ile çevrili bir köydür. Diğer köyler ilçe merkezine yakınken Çınarlı, dağlık bir alanda kurulmuştur. Bundan ötürü savaş ile ilgili haberleri ya çok geç alırlar ya da hiç haber gelmez. Eserde tarımsal üretim dağın alt tarafındaki düzlüklerde yapılarak bu mekânın kısıtlayıcı özelliği olarak anlatılır. Çünkü başka gidecekleri yer yoktur. Mecburiyet bir süreden sonra kişiler üzerinde kader haline gelip kabullenme duygusu oluşmaya başlar. Kişiler, mekânın imkânları çerçevesinde hayatlarını idame ettirir.

Aslında Çınarlı, devletin sosyal imkânlarının halka ulaşması manasında çok zor bir yerde bulunur. Çınarlı, kısıtlayıcı çevresi bakımından ele alındığında toplum tarafından hak mahrumiyetine sebebiyet verir. 
Eserde ana mekânın tasvir edilmesinden ziyade bu mekânın anlatımı ve burada yaşanan olaylar okuyucuya aksettirilmiştir. Eser vak’a zinciri içinde anlatılma kolaylığı sağlamıştır. Tasvirlere çok başvurulmadan doğrudan olaya yoğunlaşılmış ve anlatılmak istenen mesaj kolayca verilmiştir. Çınarlı, her ne kadar bir köy olsa bile roman kahramanları için büyük bir şehirden farkı yoktur. Tamamen tarımsal üretime dayalı ekonomiye sahip olan Çınarlı, kişiler üzerinde hem psikolojik hem de sosyolojik etki bırakır. Çünkü tarımsal üretimin yapılamadığı ya da ürünlerin az olduğu yıllarda köy halkı geçim sıkıntısı çeker. Oysa bolluk içinde olduğu zaman bunun karşılığını alır ve moraller yükselir.

Eserin dış mekân farklııkları arasında Çınarlı köyünün dışında adı belirtilmeyen ilçe merkezi, İğdeli, dağdaki harman yeri, erik bahçesi gibi yerler de bulunmaktadır. İlçe merkezinin dışındaki diğer yerler Çınarlı köyünün bir parçasıdır. Eserde Çınarlı'nın tasviri ve bu köy hakkında herhangi bir açıklayıcı bilgi verilmese de köydeki diğer yerler zaman akışını sağlayarak olayı canlı bir yapı haline getirmektedir. Böylece vak'a akışı, mekân ile birlikte hareketliliğini koruyarak olayların cereyan etmesini sağlar. Bu hususa bakıldığında Kerven Aga'nın Akçeşme köyünde dönemin siyasî meselelerinden dolayı bir karar alıp Çınarlı köyüne göç etmesi vak'a akışını sürdüren misallerden biri olabilir. Bununla birlikte bütün olaylar genel itibariyle Çınarlı'da ve özelde ise buna bağlı yerlerde vuku bulmaktadır.

İtibarî vak'anın anlatılığı mekânlarda, kişiler varlığını buralarda sürdürmek zorundadır. Eserde savaşın bitimi ile köy halkı sevinçlerini, paylaşımlarını yapmak için erik bahçesinde (front erik) buluşurlar. Burada eğlenir ve yemek yerler. Kolhoz işlerini yürütmek için dağdaki harman yerinde o yılın mahsulünü alırlar. Kişiler burada tarımsal faaliyetlerini sürdürür ve sosyalleşme imkânı bulurlar.

Uzak Uzak Yıllar romanında Sibirya, Akçeşme gibi atıfta bulunulan yerler dışında köyden tek çıkılan yer ilçe merkezidir. Burası hiyerarşik düzen içinde köyün bağlı bulunduğu yerdir. Ya zaman zaman buradan köye vekiller gelir. Sonra köy tekrar kaderi ile baş başa kalır. Ya da asayişi sağlamak adına ilçe milis komutanı ve askerleri gelir. Ancak bu geliş gidişler çok kısa sürmektedir.

Siyasî fikirlerin ülke politikaları üzerindeki etkisi toplumsal yapıyı da değiştirir. Böylece ülke politikaları kişilerin hayat tarzı ve yaşayış biçimi üzerinde değiştirici etkide bulunduğu için roman kahramanlarını Sibirya'ya sürgüne göndermekle tehdit edilir. Nitekim Oraz Şı ile ailesi Sibirya'ya sürgüne gönderilmiş ve sürgünde bir süre kaldıktan sonra Oraz Şıh, bir yolunu bularak Çınarlı'ya dönmüştür. Bu sürgüne gönderilme korkusu vaka sürecinde defalarca dile getirilmiştir. Ayrıca İlaman'ın dedesi Kerim Bay, zengin olduğu için değişen siyasî anlayışa ters düştüğünden dolayı ailece Sibirya'ya sürgüne gönderilmiştir. Ancak roman boyunca Kerim Bay'ın köyüne dönüp dönmemesi ile ilgili hiçbir bilgi verilmemiştir. Yazar Övezdurdu Nepesov tarafından romanda ya gizemi sürdürmek istemiştir ya da roman bu açıdan eksik bırakılmıştır.

Çınarlı köyü, roman kahramanlarının kaderi olup karakterler burada yaşamak zorundadır. Ancak romanın başkarakteri olan İlaman, bazı şeylerin değişmesi adına ikna edilerek Aşkabat'a gitmek durumunda kalır. Böylece hayatını ve yaşama biçimini değiştirerek yeni bir evreye girer. 


\subsection{Eser İç Mekânı}

Uzak Uzak Yıllar romanında olay örgüsü gerçekleşirken kullanılan mekânlar için gerekli tasvir ve açıklayıcı anlatımlardan uzak durulmuştur. Bu bağlamda mekân kavramı zayıf kalmakla birlikte iç mekân anlatımı az da olsa dış mekânın önüne geçmiştir. Çünkü roman kahramanları -lilaman, Kerven Aga, Anna, Durdı Yasavul, Ene, Akga Brigadir gibi- vak’a süreci doğrultusunda iç mekânlarda varlığını sürdürmek zorunda kalmıştır.

Eserin başkahramanı olan İlaman, bütün acılarını, sevinçlerini, hayata dair ne varsa kendi evinin içinde ya da bir başka karakterin evinde yaşamıştır. Babasının askere gideceği haberi bile evinde alır. Annesini özlemesi ve annesinin hayali ile yine kendi evinde konuşması bu konuya örnek verilebilir. Mekân unsurunun vak'a süreci içinde söz konusu etkinin ancak kişilerin duygu, düşünce ve davranışlarında belirleyici olabilmektedir. Çünkü eserin başkarakteri olan İlaman'ın evi Oraz Şıh tarafından çok kıymetli olmaktadır. Bu evin çok değerli olmasındaki temel etken ise çok eskiden eve içi altın ile dolu olan bir testi gömülü olmasından dolayıdır. Romanın başlarından itibaren Oraz Şıh, bu evi gözetler. Bir yolunu bulup da evde kazı yapmak ister. Günlerce bu evi gözetledikten sonra uygun bir zamanda eve girer ve evi kazmaya çalışır. Ancak ilk etapta bulamaz. İlaman, evini bu halde bulduğunda çok şaşırır ve evde kalmak istemez. Oraz Şıh, ikinci denemesinde eve girmeye çalıştığında Durdı Yasavul, ona engel olmaya çalışır; ancak Oraz Şıh tarafından öldürülür. Atayev tarafından Oraz Şıh tutuklanır. Oraz Şıh, eve derhal getirilir ve ev kazılmaya başlanır. Bu evden içi altın dolu testi çıkartııır. Kolluk kuvvetleri bu altınlara el koyar.

Kimi insanlar iş başa düşünce bazı yeteneklerinin farkına varabilirler. Böylece zorluk karşısındaki insanlar, döneme ve olaylara karşı hamle yapabilecek yeteneği kendinde bulabilme şansını hissedebilecektir. Tıpkı başkahraman İlaman, babası savaş için silahaltına alınmasından sonra evde tek kalması gibi. Yalnız yaşamak zorunda kalır. Ancak tek olması ve evli olamamasına rağmen teyzesi Öğretmen Üzümgül'den ev temizliği konusunda öğüt alır ve evini tek başına temizler. Düzenli olmaya çalışır. Hayatını tek başına idame ettirir.

Edebî metinlerde gizem unsurunun eseri önemli bir boyuta ulaştırdığı apaçık bir gerçektir. Çünkü gizem unsuru ile okuyucu, merak içinde eserin devamını düşünür ve olayların nereye varacağını merak eder. Böylece yazar Övezdurdu Nepesov, Uzak Uzak Yıllar romanında bir noktaya kadar Oraz Şıh'ın evi hakkında gizem unsurunu ön plana çıkarmıştır. Oraz Şıh'ın evi köylüler tarafından cinli ev olarak bilinmektedir. Böyle bilinmesinin nedeni ise vakti zamanında köye genç bir bayan öğretmen gelmesiyle köyden birine âşık olur. Ancak bu öğretmeni başkası da sevmektedir. Aşkına karşılık bulamayan bu adam, öğretmeni öldürür. Köylüler de bu iki aşığın yılda birkaç defa ruhlarının bu evde buluştukları hakkında bir hikâye uydurarak bu eve cinli ev demişlerdir. Yıllarca köy halkı bu evde olan bitenleri merak etmiş ancak içeri girmeye de çekinmişlerdir.

Olayın gelişim evreleri düşünüldüğünde II. Dünya Savaşı'nın çıkması ve Türkmen yurdunun savaşa katılması, eserdeki önemli olaylardandır. Nitekim bu önemli olayın şahıslar üzerindeki etkisi büyük olacaktır. Uzak Uzak Yıllar romanının en bahtsız 
karakterlerinden biri olan Sülgün'ün çok güzel bir hayatı vardır. Ancak savaş çıkması ile birlikte kocası Muratı savaşa gönderilir. Bundan sonra Sülgün için zor günler başlar. Sülgün'ün evi artık hastalık ve sefalet evi olmaktan öteye gidemez. Zor günlerin getirdiği fakirlik, evin her hâlinden gözlemlenmektedir. Yokluk, Sülgün'ü bir avuç buğdaya muhtaç bırakır. Sülgün'ün evi açlık ve hastalıktan dolayı iki çocuğa mezar olur. Çocukların cenazesi bu evden çıkar ve romanın sonlarında bu ev, bir harabeye döner. Sülgün ise bu evin içinde artık deli olan biridir.

İnsan doğası gereği sığınacak bir liman arar. İlaman, yalnız olduğu zamanlarda derdini paylaşacağı ve dayanacağı bir yer arar. İlaman, Üzümgül'ün kendi teyzesi olduğu bilgisine ulaştığında teyzesi onu içgüdüsel olarak korumaya alır ve kendi evini ona açar. İlaman ile birlikte yaşar.

Romanın kötü karakterlerinden biri olan Ene ve annesinin yaşadığı ev çok şatafatlı olmasa da toplumsal düzen içinde hatırı sayılı bir konumdadır. Hiç kimsenin evinde bulunmayan yiyeyecek ve içecekler bu evde bulunur. Ancak ne kadar bolluk olsa da bu evin içinde huzur ve mutluluk yoktur. Zaten eserin sonlarına doğru Ene vicdan azabı ile uğraştıktan sonra ölüm ile hayata veda eder.

Sovyet yönetim anlayışının hâkim olduğu Çınarlı köyünde kolhoz çalışma hayatı, insanların iş deneyimleri üzerinde baskı yapacaktır. Bütün kararlar İnkılap Kolhozu'nda alınacak ve bütün işler buna göre yürütülecektir.

Üzerinde durulması gereken bir diğer mekân ise ilçe merkezindeki milis karakoludur. Bu karakolun içi tipik jandarma karakolunu andırır ve suçluların korktuğu mekânların başında gelir.

\section{Romanın Kahramanları}

İtibari bir metnin olmazsa olmazı olan kişi kadrosu kurgulanırken romanın ana ve yardımcı karakterleri bulunur. Bu karakterlerin bulunması ile romana bir ivme kazandırılır. Uzak Uzak Yıllar romanında bu ivme romanın ana karakteri olan İlaman tarafından gerçekleştirilir. Bütün vaka ve zaman, İlaman'ın etrafında şekillenmiştir. Yardımcı karakterler ise İlaman'a verilen görev doğrultusunda ona ya yardımcı olur ya da onun karşısında bulunurlar. Böylece Uzak Uzak Yıllar romanının kahramanlarını şu şekilde sıralayabiliriz:

\subsection{Roman Ana Karakteri}

\section{İlaman}

Uzak Uzak Yıllar romanının aslî karakterlerinden biri olan İlaman, üç bölümden oluşan romanın bütün evrelerinde varlığını hissettirir. İlaman, Kerven Aga ile Sona'nın oğludur. Çınarlı köyüne taşındıkları yıl İlaman doğar. Ancak dört yaşına geldiğinde annesi Suna'yı kaybeder. Çok erken yaşta annesini kaybetme acısının içinde olması ve babasının savaşa gitmesi İlaman'ı hüzünlü bir yapıya sürükler. İlaman böylece kalabalığın içinde kendini zaman zaman yalnız ve çaresiz hisseder.

İlaman, dönemin zor şartlarına rağmen aldığı eğitim ile birçok insandan farklı olduğunu gösterir. Kendini geliştirmenin önemini özümseyerek tahsilini tamamlamak istemiştir. Ancak çıkan savaştan dolayı her ne kadar eğitimine ara verse de daha 
sonraki dönemlerde bunun üstesinden gelmiştir. Böylece ideal karakter anlayışının tipik bir örneği olarak karşımıza çıkar.

Bütün olumsuz durumlara rağmen İlaman'da var olma anlayışı hâkimdir. SSCB hâkimiyeti altındaki Türkmenistan'ın II. Dünya Savaşı'na katılması ile birlikte yoksullaşıp ekonomik anlamda birçok sorunun ortaya çıkmasına zemin hazırlayacaktır. İlaman'ın ruhsal yapısını etkileyecek bu etmenler onu hâliyle çok yıpratacaktır.

İlaman, Türk kültürüne ve gelenek göreneklerine bağlı olarak kurgulanmıştır. Yazar, İlaman'ı Türkmenistan sınırları dışına çıkarmayarak bu coğrafyayı ona yurt edindirmiştir. Doğal olarak da o yerin kültürünü bize sunacaktır.

Önce annesinin ölümü sonra da babasını savaşta kaybetmesiyle yalnızlaşan İlaman, daha sonra ise teyzesi Üzümgül'ü tanıyıp kendisinden maddi ve manevî bir güç alacaktır. Bu gerçek anlaşıldıktan sonraki süreçte İlaman'ın kaderi üzerinde olumlu birçok etki yapacaktır. Böylece İlaman'ın kendine güveni gelecek ve hayata bakışı değişecektir.

\subsection{Roman Yardımcı Karakterleri}

\section{Kerven Aga}

İlaman'ın babası ve Sona'nın eşidir. Kerven Aga ile ilgili bilgiler sadece romanın birinci bölümün altıncı maddesine kadar olan kısımda tespit edilmektedir. Diğer bilgiler ise savaşa gittikten sonra Gurban Çarı tarafından yazılan mektuplar aracılığı ile anlaşılmaktadır.

\section{Kolhoz Başkanı Anna}

Köydeki kolhozu yöneten kişidir. Romanın başlarında Kerven Aga'ya karşı tutumu biraz sert olsa da romanın ilerleyen sayfalarında babacan tavırları ile dikkatleri üzerine çeker.

Kolhoz başkanı Anna, hem köyünde bir lider olarak ender kişilerden biri olarak karakterize edilir hem de dönemin siyasî rejiminin koruyucusu olarak değerlendirilebilir. O kendi içinde millîyetçilik duygusunu derinden hissederek ülkesini, Sosyalizm'i ve SSCB'nin değer yargılarını benimsemiştir. Böylece ülkesini korumak için elinden geleni yapar.

\section{Durdı Yasavul (Muhafız)}

Durdı Yasavul, kolhoz başkanı Anna'nın emrinde çalışmasına rağmen onun en yakın arkadaşı, sırdaşıdır. Anna ile arkadaşlığı çok eskilere dayanır. Onun sözünden hiçbir zaman çıkmamış ve emirlerini daima yerine getirir. Böylece Durdı Yasavul, bir görev adamı olduğunu ispatlayarak ömrü boyunca mesleğini en iyi şekilde yapar. Romanın sonlarına doğru Oraz Şıh tarafından öldürülür.

\section{Sülgün}

Sülgün, İlaman'ın komşusudur. Eşi Muratlı'nın savaş için askere gitmesinden sonra hem maddi hem de manevî anlamda çok zor günler geçirir. Romanın İlaman'dan sonra en metanetli karakteri olma özelliğini taşır. Çocukalını kaybetmesi üzerine romanın sonlarına doğru aklî dengesini kaybeder. 


\section{Muratlı}

Sülgün'ün eşidir. Romanda onun hakkında pek fazla bilgi verilmemektedir. Duvarcılık işi ile uğraşır. II. Dünya Savaşı'nın çıkmasıyla askere alınır. Savaş boyunca ondan haber alınmaz. Sonunda ölüm haberi gelir.

\section{Öğretmen Üzümgül}

İlaman'ın öz teyzesidir. Çınarlı'da öğretmenlik yapar. Aynı okulda görev yapan Bezirgen'in eşidir. Bezirgen, savaş için silah altına alınınca köyde yalnız kalır. Okuldaki bütün yük onun sırtına yüklenir.

Üzümgül, namusuna düşkün biridir. Bütün gücüyle eşi Bezirgen'e sadık olarak yaşar. Akga Brigadir'in ona yanaşmasına izin vermeyeceği gibi kendisinin de Ene olmadığını Akga Brigadir'e söyleyerek ona sert çıkışmıştır.

Üzümgül, savaş bittikten sonra Aşkabat'ta bir iş bulur. İlaman'ı da yanında götürerek eğitimine katkı sağlar. İlaman'ın başarılı bir hayatının olmasında Üzümgül'ün büyük bir payı vardır.

\section{Goçaklı}

Goçaklı, Kerven Aga'nın kardeşi ve Ene'nin kocasıdır. Savaş çıktığında köyden askere alınan ilk kişilerdendir. Romanın sonlarında savaş bitimi ile köye geri gelir. Karısı Ene'nin ölümü üzerine iki çocukla yalnız kaldığını düşünerek Oğulteç ile evlenir.

\section{Ene}

Romanın kötü karaterlerinden biri olan Ene, kocası Goçaklı'nın askere gitmesinden sonra Akga Brigadir ile aşk yaşamaya başlar. Romanın sonlarına doğru bu yaptığından dolayı çok pişman olur. Karakter olarak psikolojik çöküntü içinde varlığını sürdürür. Ancak bu çöküntünün farkında olmadan yavaş yavaş kendini bitirir. Travmalar, bir dizi ruhsal ve ahlakî süreç içinde Ene'nin aklını zehirleyerek ve onu ölüm denilen nihaî sonuca götürür.

\section{Meretgül}

Romanın kötü karakterlerinden biri olan Meretgül, Ene'nin annesidir. Ene'nin yanlış kararlar almasında etkili rol oynayan kişidir. Akga Brigadir'in nüfuzlu biri olması Meretgül'ün iştahını kabartır. Onun sayesinde refah içinde yaşayacağını düşünür.

\section{Akga Brigadir ${ }^{2}$}

Romanın bir diğer kötü karakterlerinden biri olan Akga Brigadir, Çınarlı köyündeki İnkılap Kolhozu'nda ekip başıdır. Statü olarak diğer köylülerden daha avantajılır. Bu nüfuzu yeri geldiği zaman kullanmaktan çekinmez.

\footnotetext{
${ }^{2}$ BRIGADiR a. Rus. Ekip başı, ekip şefi, grup başı, grup şefi.
} 
Akga Brigadir, evli olmasına rağmen Ene ile yasak aşk yaşar. Ene'yi kuma olarak getirmek ister. Ancak Goçaklı'ya ihanet ettiğini düşünmesiyle vicdan azabı çeker ve pişman olur.

\section{Oraz Şıh}

Kötü karakterler içinde sıralanan Oraz Şıh, Çınarlı köyünün asıl yerlilerindendir. Zengin bir aileden gelir. Dedesinin şeyh olmasından dolayı kendisine şı yani şeyh olarak isim verirler. Türkmenistan'ın Sovyetler Birliği'ne katılmasıyla köyde burjuvazi olarak nitelendirilir. Ağa oldukları için Sibirya'ya sürgüne gönderilir. Bütün malları kolhoza devredilir.

Oraz Şıh, Sibirya'daki sürgünden bir şekilde kurtularak Çınarlı'ya geri döner. Sürgüne gitmeden önce İlaman'ın evine gömdükleri altını çıkarmak için uğraş verir ve İran'a kaçma planları yapar. Evde kazı yapmak istediği sırada Durdı Yasavul onu tutmak ister; ancak hırsının esiri olarak Durdı Yasavul'ı öldürüp kaçar. Bir süre sonra yakalanır.

\section{Doktor Azru}

Çınarlı köyünde geleneksel yöntemler ile hekimlik yapmaya çalışan biridir. oğlu Serdar'ı savaş için askere gönderdikten bir süre sonra oğlunun ölüm haberini alarak yıkılır. Bunun üzerine hastalanarak ölür.

\section{Sapargül (Sapar Durdı)}

Romandaki iyi karakterlerden biri olmaya çalışan Sapargül, Çınarlı'daki kolhozda brigadir olarak görev yapar. Haksızlığı sevmeyen bir yapısı olup brigadir olmanın avantajını Akga Brigadir gibi kullanmaz. Birine yardım edilecekse önce o yardım eder.

\section{Hudayberdi}

Roman karakterlerinin en haylazı olan Hudayberdi, cesareti ve çalışkanlığı ile ortaya çıkar. Oğulteç'in sevgilisidir. Güçlü bir yapıya sahiptir. Önceleri İlaman ile gerginlik yaşasa da sonraları İlaman ile sıkı dost olur. Savaş çıktığında askere alınır. Savaştan dönmeyen karakterlerdendir.

\section{Oğulteç}

Romanın başlarında Hudayberdi ile sevgili olan Oğulteç, çok çalışkan bir genç kızdır. Hüdayberdi'nin askere gitmesinden sonra İlaman ile yakınlaşmaları başlar. Ancak İlaman savaş bittikten sonra teyzesi ile Aşkabat'a gittikten sonra Goçaklı ile evlendirilir.

\section{Tagı Gelin}

Kolhozda çalışan işçilerden biridir. İyi niyetli bir kadındır. Durdı Yasavul'un ölümü üzerine çok üzülür. Köyde olan bitenden biraz olsun haberdardır.

\section{Atayıf (Atayev)}

Atayıf, ilçe merkezinde milis komutanıdır. Kolhoz başkanı Anna'nın Oraz Şı Akga Brigadir hakkında olumsuz görüşü üzerine harekete geçen ve bunun için köye 
asker gönderen kişidir. Durdı Yasavul'un Oraz Şı tarafından öldürülmesi üzerine arama faaliyetleri için askerlerine emir vererek Oraz Şıh'ı yakalatır.

\subsection{Romandaki Dekoratif Karakterler}

İtibarî metinler vücuda getirilirken bir takım kişilerin kendi aralarındaki etkileşimi, romanın hangi yöne doğru gideceği konusunda bir fikir verir. Bu kişiler olay örgüsünü doğrudan yaşayacak olan ana karakter ya da yardımcı karakterler olarak okuyunun karşısına çıkar. Ancak kimi zaman bazı kişilerin romanda ya etkisi çok az olur ya da hiç yaşamayan biri hakkında bilgi verilir. "Bu itibarî varlıklardan bir kısmına vakanın zuhuru için ihtiyaç duyulur. Bir kısmı dekoratif unsur olarak eserde vazife görür.” (Aktaş 2005: 137). Bu eserdeki dekoratif karakterleri şöyle sıralamak gerekirse:

Kerim Bay, Sona, Aysoltan ile Nursoltan, Vekil, Bezirgen, Serdar, Duvsayep, Akcagül, Nurı, Seyit Şıh, İtalmaz, Atabay Orazmemmet, Arpagül ile Danegül, Serdarın asker arkadaşı, Şiri ile Piri, Arzıgül ile Durdı, Sabır Aga'dır.

\section{Temalar (İzlek)}

Edebî eserlerde yapıdan sonra en önemli unsurlardan biri temadır. Tema konunun özel bir şekilde yazar tarafından ele alınmış ayrıntısıdır. Yazarın eseri daha detaylı bir şekilde okuyucuya aktardığı ve eserine derinlik kattığı bir unsur olarak ifade edilebilir.

Uzak Uzak Yıllar romanında Övezdurdu Nepesov'un savaş ve savaşın sonuçlarını İlaman karakteri üzerinden Türkmen halkına olan etkiyi ortaya koymakla kalmayıp konu bütünlüğü içinde ayrıntıya girerek toplumun ve bireyin üzerindeki etkisini ifade etmeye çalışmıştır.

Övezdurdu Nepesov'un Uzak Uzak Yıllar romanı, tematik olarak ortaya koyulduğunda Türkmenler üstündeki etkisinin belirlenmesi bakımından toplumsal içerik; şahıslar üzerindeki etkisi düşünüldüğünde ise bireysel içerik olarak değer kazanmaktadır:

\subsection{Toplumsal İçerik}

\subsubsection{Aile Kavramı}

Bir toplumun önemli yapı taşlarından biri olan aile müessesi, hiç şüphe yoktur ki Türkmen toplumunda da önemli bir yere sahiptir. Türkmenler, tarih boyunca birçok savaş ve doğa olayları gibi toplumu derinden etkileyen olumsuz koşullara maruz kalmasına rağmen değer yargılarını muhafaza edip gelecek kuşaklara daha güçlü bir şekilde kültürel miras bırakabilmişlerdir. Böylece Türkmenler aile bağlarını güçlü bir şekilde muhafaza edebilmiştir.

Uzak Uzak Yıllar romanında aile bağlarını ve aile olmanın önemini birçok defa vurgulanarak ortaya konmuştur. Yazar Nepesov tarafından aile temasını bu düşünce doğrultusunda derinleştirmeyi sağlamıştır. Ancak savaş yılları ve bunun sonuçlarını romana konu alan yazar, aile kurumunun zaman zaman sarsıldığını gözler önünde sergilemekten kaçınmamıştır. Roman kahramanlarının psikososyal yaşamlarında derin izler bırakmaktadır. 
Sovyet rejiminin Türkmenistan'da hüküm sürdüğü yıllarda Sovyet görevlileri varlıklı kişileri tek tek tespit eder. Bunlardan biri olan Kerim Bay, varlıklı olduğu için elinde ne varsa devlet tarafından el konularak Sibirya'ya sürgüne gönderilir. Kerim Bay ise ailesine zarar gelir düşüncesiyle yanında götürürür. Ancak Sona'yı götürmek istemez ve tren istasyonunda Kerven Aga'ya emanet eder.

İnsanoğlunun doğası gereği evlenip bir yuva kurma intiyacı hisseder. Bu yuvada mutlu olmak ve çocuk sahibi olmak ister. Kerven Aga da Sona'yı babasından emanet aldıktan sonra onu korur ve nihayetinde Sona ile evlenir. Kerven Aga, Sona ile evlendikten sonra baskılara maruz kalır. Kerim Bay'ın kızı ile evlendiği için kolhozdaki işinden olur. Sonra Akçeşme'de yapamayacağını anlar ve ailesini korumak için Çınarlı'ya göç eder.

Hudaýberdi, köyün en yaramaz, bir o kadar da en çalışkan gençlerinden biridir. Ogultäç adında bir kızı sever. Onunla ilerleyen yıllarda evlenip bir yuva kurmak isterek aile olma planları yapar.

Türk dünyasında olduğu gibi Türkmenler'de de evlenme/evlendirme, geleneklere bağlı bir şekilde hüküm sürer. Evlenecek bireyin ebeveynleri, çocukların evliliklerine hazırlık yapmak ister. Böylece çocuklarının mürüvvetlerini görmek isterler. Uzak Uzak Yıllar romanı itibariyle bu durumu görmek mümkündür. Kerven Aga ile Sona, oğulları olan İlaman'ın evliliğini görmek isterler. Sona, İlaman evlendiğinde gelinine bir takı takmak ister. Ancak buna ömrü vefa etmez. Bunun için eşi Kerven'e vasiyet ederek gelinine bir takı takmasını söyler:

"Ine, şu ejeňden galan şaý. O pahyr «oglum öýlense, gelnime dakaryn. Halal zadym» diýip köp aýdardy. Emma näme, boldumy? Adamçylykdyr, sen şuny al. Eger- de..." (Nepesow 1986: 36)

(Yine de annenden kalan tek şey budur. O fakir, "Oğlum evlense gelinime takarım. Helal bir şeydir." deyip çokça söylendi. Ama, ne oldu? İnsaniyetliktir. Sen şunu al. Eğer...)

Yazar Övezdurdu Nepesov, her ne kadar II. Dünya Savaşı yıllarını yaşı itibariyle canlı olarak yaşamasa da savaşın olumsuz yönlerini ve Türkmen toplumunun üzerindeki etkisini, sonuç olarak romanda derinlemesine hissettirmeyi başarabilmiştir. Savaşın söz konusu en önemli etkisi ise ölüm ile sonuçlanarak aile düzenini sarsacak ve birçok aileyi derinden etkileyecektir:

Geleneklerine bağlı Türkmen toplumunda aile yapısı oldukça geniş bir sistem içinde varlığını sürdürür. Bu sistem geniş bir yapıda olup aile bağları kapsamlıdır. Bütün dünyada olduğu gibi Türkmenistan'da da II. Dünya Savaşı'nın etkisi büyük bir yıkım olarak görülmekte ve aile üyeleri olumsuz olarak etkilenmektedir. Türk ananeleri içinde aile bütünlüğüne bakıldığında ailede anne, baba ve çocuklar ile bunların yanında anneanne, dede ya da babaanne, teyze, hala, dayı ve amca gibi bireylerin bir arada yaşadığı görülmektedir. Böylece aile bağları daha güçlü olarak yaşlı bireylerin karar alma mekânizması daha güçlü olmaktadır. Aileyi bir arada tutmakta ve bazen yanlış karar alınsa bile ailenin diğer bireyleri bu alınan karara uymak zorunda kalabilmektedir.

\subsubsection{Savaş Kavramı}


"Savaşlar, pek çok milleti doğrudan ya da dolaylı olarak tesiri altında bırakan, etkileri uzun süre devam eden toplumsal bir hadise olarak tarih kitaplarında yerini alır." (Güldürmez 2018: 217) Bu elim olay, insanoğlunun ilk günlerinden beri kimi zaman insanların hırsları ve çıkarları münasebetiyle kimi zaman da millî benliğini ve bağımsızlığını korumak adına ortaya çıkıp kendini göstermeyi bilmiştir. Savaşın etkileri kundaktaki bebekten 70 yaşındaki intiyar bir bireye kadar yansır.

Uzak Uzak Yıllar romanının ilk sayfasında " Uruş adamzadyň başyna nähili agyr günleri saldy." (Nepesow 1986: 1) (Savaş insanların başına birçok ağır günler getirdi) denilerek savaşın insanlar üzerindeki olumsuz etkisini özetler nitelikte gözler önüne sermektedir.

Savaşın olumsuz etkileri genelde tüm dünya ve Sovyetler Birliği'nde özelde ise Türkmen coğrafyasında kendini büyük bir hadise olarak gösterir. Böylece roman kahramanlarının tamamı bu olumsuz durumdan etkilenir. Aileler parçalanır. İnsanlar büyük bir ekonomik çıkmaza girerek yanlış ve toplum tarafından tasvip edilmeyen hal ve hareketlere maruz kalarak hayatını belli bir yere kadar idame ettirirler:

Ene, eşi Goçaklı'nın savaş münasebetiyle askere alınmasından bir süre sonra yalnızlık çeker. Ancak kolhozda çalıştığı sırada Akga Brigadir ile yakınlaşır. Bu yasak ilişkiye annesi Merekgül'ün de onayı ile bu ilişki devam eder. Bir süre sonra vicdan muhakemesi yaparak yaşadığından dolayı çok pişman olur. Sonunda ise ölüm ile yaşamı son bulur.

Savaş denilince ilk akla gelen kelimelerin başında ölüm gelir. Ölüm, hayatın son bulması, dünya ile bir bağının kalmaması anlamına gelmektedir. Ölüm, beraberinde parçalanmış hayatlar bırakır. Böylece bu romanın ana temalarından biri olan savaş ve ölüm temaları Sovyet coğrafyasındaki Türkmenistan'ın yoksul olan bir tarafını daha da çıkmaza sokarak savaş ile birlikte ölümü getirir:

II. Dünya Savaşı'nın çıkmasından sonra Sülgün'ün eşi Muratlı silah altına alınır. Sülgün bu durumdan hem maddi hem de manevî olarak çok etkilenir. Savaştan dolayı fakirleşen ve çaresizlik içinde kalan Sülgün, kızları Nursoltan ve Aysoltan'ı kaybeder;

Sebep ve sonuç ilişkisi münasebetiyle vak'aya bakıldığında II. Dünya Savaşı'nın sonuçları çok ağır olmuştur. Aileler savaşın etkisi ile parçalanmış ve aile bireylerinin bir kısmının savaşta ölmesi ile aile kurumunun ağır bir yara almasına neden olmuştur. Nitekim bahis konusu cihan harbiyse sonuç olarak parçalanmış hayatlar da çok olmuştur:

Annesini daha önceden kaybeden İlaman, savaşın çıkması ile birlikte babasını savaşmak için askere gönderir. Savaşın yıkıcı sonuçlarından olan ölüm haberini bir süre sonra Kerven Aga'nın arkadaşı Gurban Çarı getirir. İlaman, bu acı haber üzerine derin bir üzüntü hissederek ailesinin en önemli ferdi olan babasını yitirmiştir. Böylece uzun sürecek bir yalnızığın içine girecektir.

Romanda savaşın çıkması Türkmenler için büyük bir sürpriz olması ile birlikte birçok kişi zorunlu olarak silahaltına alınır. Kimi eşinden ayrılır, kimi çocuğundan, kimi ise yurdundan ayrılmak zorunda kalır. Her ne kadar savaşı sıcağı sıcağına yaşayan karakterler olsa da savaş gerisindeki bireyler ise bu cefayı savaşır gibi hissederler. Savaş her bir karaktere farklı farklı ayrılık acısını tattırır. İlaman babası Kerven'i, 
Üzümgül kocası Bezirgen'i, Doktor Arzu'nun oğlunu özlemesi ile ayrılık ateşinin her bir bireye ayrı ayrı düşmesi bakımından romanın olay örgüsünde dramatik kurguya neden olmaktadır.

Sovyet rejimi etkisi altında olan Türkmenistan'ın II. Dünya Savaşı'na asker göndermesi, birçok ülkede olduğu gibi Türkmenler üzerinde de olumsuz etki yaratmıştır. Savaş sonucunda fakirleşen halk günlük gıda ihtiyacını bile karşılayamaz duruma gelir. Yazar Nepesov, savaş ile gelen yoksulluğun halk üzerindeki etkisini Uzak Uzak Yıllar romanında gözler önünde sergilerken karakterlerin hayat ile olan kaygılarını da anlatmaktan çekinmemiştir. Roman karakterleri kolhozda çalışmaktan çok yorulmuş; ancak hiçbir çaresi olmayan insanların bir lokma için bu duruma direnecek güçlerinin olmadığı anlaşılmıştır. Nitekim Sovyet siyasal sistemi de Türkmen halkını bir bütün içinde rejim çıkarları doğrultusunda kullanmıştır. Böylece halkı kendine bağlı kılmasını başarabilmiştir. Romanın olay örgüsünde sunulan savaş gerisindeki yoksulluk ve akabinde gelen birtakım sorunlar bu durumu özetler nitelikte kendini göstermiştir.

Savaş, birçok olumsuz duruma yol açsa da ulus devletlerine millî birlik ve beraberliği de getirir. Türkmen halkı binlerce vatandaşını Sovyetler Birliği için savaşa göndermişse de savaş ardında kalanlar birlik içinde bu olumsuz ekonomik çıkmazdan kurtulmak için canla başla kolhozda çalışma gayreti gösterir:

"Ýagdaý näçe agyr bolsa-da çydarys. Duşmany hökman ýeňeris. Ýeňiş indi daşda däl, ýoldaşlar! Siziň her gysym kauçugyňyz, her baş bugdaýyňyz, her bir zarpçy zähmetiňiz duşman üçin gülledir.” (Nepesow 1986: 60)

(Durum ne kadar ağır olsa da dayanırız. Düşmanı gerçekten yeneriz. Galibiyet şimdi uzakta değil, yoldaşlar! Sizin her kısım kauçuğunuz, her baş buğdayınız, her bir gücünüz düşman için gülledir.)

\subsubsection{Yoksulluk}

Romanda yoksulluk teması, Türkmenlerin her faaliyet alanında kendini gösterir. Eserde yaşamın her kesiminde kendini hissettiren yoksulluk, kişilerin aile yaşantılarında, almış olduğu ya da alacağı eğitimde, insanî ilişkilerde ve şahısların kişiliği üstünde açıkça görülmektedir.

Romanın olay örgüsünden hareketle romandaki fertlerin tamamına yakını üzerinde etkisi hissedilen yoksulluk teması Sülgün özelinde özetlenerek bu trajediyi gözler önüne sergilenebilir:

“Insanları kimi zaman kişiliksizleştiren, hata yapmaya zorlayan, ezen, küçülten bir olgudur, yoksulluk. Romanda çatışma zemininin oluşmasında etkin bir şekilde karşımıza çıkmaktadır." (Eronat 2010: 98) Böylece Ene, eşini askere uğurladıktan sonra bir müddet yalnız kalınca gelişen ve bu durumu pekiştiren yoksulluğun bir kamçı gibi sırtına vurmasıyla hata yapmaya sebep olur. Ene'nin bu durumu annesi Meretgül'ün kişiliksiz davranışlarıyla destekler nitelikte karşımıza çıkmaktadır:

Meretgül, Ene'nin Aga Brigadir ile münasebeti ilerletmesini arzu eder. Nitekim Akga Brigadir'in mevkisinden yararlanarak içindeki sefil hayata son vermek ister. 
Yoksulluk kimi zaman kişileri yalnızlaştırarak ötekileştirme süreci içinde kişiyi kendi iç dünyasına hapsettirir. Kişi, ya yoksulluğun vermiş olduğu yalnızlık ile birlikte içe kapanık bir hayat yaşar ya da ruhsal devinimler yüklenerek karakterin daha güçlü olmasına katkı sağlar. Romanın başkahramanı olan İlaman'ın bu süreçte yoksulluk ile birlikte kendi iç dünyasına sığınması ve daha güçlü bir karakter olarak ortaya çıkıp kendini ispatlar duruma getirmesi karakter bakımından daha güçlü olmaktadır.

\subsubsection{Ayrılık}

"Türkçe'de ifadesine rastladığımız "ayrılık" kavramı, daha çok ölümle gelen bir ayrıığın, uzak düşülen varlığa duyulan bir özleyişin ifadesidir.” (Yalçınkaya, 2018: 323) Bu özleyiş kimi zaman bir babayı, kimi zaman bir evladı, kimi zaman da bir eşi özlem duygusu içinde hissettirir. Romanında konu bütünlüğü bakımından savaşı ele alması, karakterleri bir ayrılığa sürüklemiş ve vuslat beklentisi içinde ruhî devinimlerle başbaşa bırakmıştır.

Romandaki karakterler savaşı hep olumsuz bir durum olarak gördüklerinden savaş onların nazarında ayrılığa sebebiyet veren bir düşman olmuştur:

"Kerwen aga özüni saklap bilmedi. Ol llamany bagryna basdy. Soň onun̆ ýaňaklaryndan taýly gözek öpdi-de, yzyna garaman gitdi.” (Nepesow 1986: 36)

(Kerven Aga, kendini tutamadı. O, İlaman'ı bağrına bastı. Sonra onun yanaklarından tek gözünden öptü de, arkasına bakmadan gitti.)

Savaş çıkmasından itibaren başlarsak karakterlerin çoğu en az bir yakınını savaşa göndermiş ve savaşın çıkmasıyla ayrıığa düşmüşlerdir. Bu ayrılık kimi zaman ölümle neticelenmiş. Kimi zaman da uzun süren bir bekleyişin nihayetinde vuslat ile taçlandırıımıştır.

\subsection{Bireysel İçerik}

\subsubsection{Aşk}

"Aşk konusu her yönü ile dünya edebiyatı tarafından asırlarca kullanılmış bir olgudur." (Kaya 2012: 106) Bu olguyu güçlendirecek yegâne varlık insan olmuş ve dünyanın çeşitli edebiyatlarında daima kendine yer edinmiştir. Birçok yazar ve şair, aşkı ele alıp eserlerinde işleyerek benzersiz yapıtlar üretmişlerdir.

Uzak Uzak Yıllar romanında her ne kadar konu bütünlüğü savaşı ve savaşın insan üzerindeki kaçınılmaz etkisini ele alsa da roman kahramanlarının aşk üzerindeki derin ve karşı konulamaz hislerini görmek mümkündür. Nitekim bu duyguyu anlatmakta kimi zaman bir materyali, kimi zaman da geçmişin zihinlerde kaldığı bir yansıması olarak aşkı görmek gerekir. Böylece karakterlerden bazıları aşkı tatma erdemine ulaşmışlardır.

"Aşk, sevenin sevilenden başka bir şeyi gözünün görmemesi, sevgiye dair her şeyin sevgiliyi hatırlatıp güzel ve yaratılmış tüm varlıkların sadece sevgiliyi hatırlatmasıdır." (Kaya 2012: 106) Romanda kişiler aşkı doğrudan fizikî birer meta olarak görmeyip hep geçmiş ile ilgili hatıralarda saklanan ve canlılığını hep koruyan bir anı olarak görmüşlerdir. 
Romanda zaman zaman aşkı hissedici emareler olsa bile yazar, bu duyguyu kahramanlara vak'a zamanı bağlamında çok az tattırmıştır. Karakterlerin birkaçı aşkı hissetme eğilimi göstermiş ancak eserde bir duygu yoğunluğu olmamıştır.

Aşkı bazen karşı cinse duyulan aşırı sevgiden ziyade anneye duyulan özlem olarak telaffuz etmek mümkündür. Romanın başkahramanı olan İlaman, olay örgüsündeki zaman sürecinde annesini düşünerek zaman zaman annesinin hayaliyle konuşur ve aşk temasını bizlere hatırlatır. Böylece sevgisini hep canlı tutarak hayat ile ilgili bağını koparmaz.

Zamana, mekâna ve olaylara göre değişebilen aşk, içine girdiği kalpte, kişileri yönlendirebilme içgüdüsü olduğu söylenebilir. Geçmişin tecrübelerine karşı çaresiz bırakan ve kader algısını yasak aşka dönüştüren Ene'nin Akga Brigadir ile yaşadığı yasak aşkı diğer karekterlerden ayıran yazgısını, kendi elleriyle başlatıp ve nihayetinde kendi kendinin sonunu getirmesi bakımından trajik bir hadiseye olan yolculuğu aşk temasıyla nitelendirilip romanda gözler önüne sermiştir.

\subsubsection{Kaçış}

"Dış dünyanın gerçekleri ile çepeçevre kuşatıldığını hisseden insan ruhu, ilk devirlerden günümüze kadar hep bu "kuşatmışlık" sıkıntısından kurtulmaya uğraşmıştır." (Korkmaz 2002: 164) Kimi zaman dış dünya, insan ruhunu kendi bedenine hapsederek tezahürü imkânsız çıkmazlara sokmuştur. Daralan insan ruhu bu olumsuz hakikatten uzaklaşmak için kaçış evresine girecek ve bu durumdan kurtulmak isteyecektir.

"Şefkatli bir kadın, gece gibi ayıpları ve kusurları örten, insanı teselli eden bir huzur kaynağıdır." (Korkmaz 2002: 167) Böylece Illaman, ruhsal çıkmazlar ile baş edemediği zamanlarda annesinin hayaline sığınarak huzur bulmak istemiştir. Dış dünya ile bağını koparan İlaman, annesinin hayaliyle başbaşa kalarak annesinin kucağına sokulur ve sorunlardan kaçmak ister.

Romandaki sıkıcı, boğucu ortam kaçış zeminini hazırlamış, mutsuz ve arayış içinde varlığını sürdüren, içinde bulunduğu sosyal ortam ile bütünleşemeyen kişiler kaçış davranışının insan üzerindeki rahatlatıcı büyüsüne kapılmışlardır. Nitekim Kerven Aga da böyle bir dış çevreden başka bir dış çevreye yönelimi söz konusu olmuştur:

Kerven Aga'nın Sona'yla evlenmesi neticesinde "Kerim Bay'ın kızı ile evlenmiştir." denilerek önce onu kolhozdan çıkararak işinden ederler. Sonra da Akçeşme'de duramayacağını anlayan Kerven Aga, Çınarlı'ya göç etmek zorunda kalır.

Kaçış sendromu kimi zaman yeni kapıların açılmasına vesile olmaktadır. Kaçma davranışı, bütün ümidini kaybeden bireyde başka ümitlerin yeşermesine zemin hazırlar. İlaman, tam bu noktada ani bir karar vererek teyzesi ile Çınarlı'dan çıkıp Aşkabat'a yerleşir. Burada okuyup önemli bir makama erişir ve bu kaçma davranışı ona olumlu olarak yansır.

Goçaklı'yı savaşa gönderen Ene, yalnız kaldığını hissettiği anda Akga Brigadir ile yasak aşk yaşamaya başlar. Ancak bir süre sonra yaptığının yanlış olduğunu anlayan Ene, çok pişman olur. Kendini kaybederek hatasını telafi edemez. Ene, elem 
dolu bir yaşam içinde olduğunu düşünerek trajik bir son ile kaçma eğilimi içinde hayata veda eder.

\subsubsection{Yalnızlık}

Yalnızlık, insanı kendi benliğine hapseden, çevresel ve ruhsal temellere dayanan bir sonuç evresidir. Yalnızlığı besleyen, ona zemin hazırlayan birden çok etken olmasının yanında romanın ana teması olan savaşın insan üzerindeki etkileri dikkatlice irdelendiğinde savaş faktörünün insanları önce sevdiklerinden uzaklaştırdığı, sonrasında ise yavaş yavaş yalnızlaştırdığı anlaşılmaktadır. Nitekim roman karakterlerinin tamamı halkın arasından çıkmış bireyler olmasıyla birlikte bireylerin tamamına yakını eleştirel yetilerini kaybetmiş olup insanların parçalanmış aileler özelinde yalnızlaştığı görülür.

Uzak Uzak Yıllar romanında iki türlü yalnızlıktan bahsetmek mümkündür. İlki maddi yani bedensel yalnızlıktır. Bu yalnızlığa Ene örneğini vermek mümkündür. Ene eşi Goçaklı'nın savaş için silahaltına alınmasından sonra tensel bir yalnızlık çeker. Bu bedeni yalnızlık buhranından kurtulmak için Akga Brigadir'le yakınlık kurar. Böylece istediğini nispeten almış olur. İkincisi ise ruhsal süreci hazırlayan manevî yalnızlıktır. Bu yalnızlık birçok kişide felaketi yaşatacak bir yalnızlıktır. Tıpkı Ene'nin bedensel arzularını elde etmek için Akga Brigadir ile yakınlaşma süreci ruhsal evrede de kendini hissettirir. Bu yakınlaşma bir süre sonra pişmanlık ile son bularak Ene'ye kendi felaketini yaşatır.

"Yalnızlık, bedensel ve ruhsal anlamdaki telakkileri aşarak ölüm fikriyle bütünleşir." (Korkmaz 2002: 153) Bu fikir romandaki yalnızlaşan karakterlerin çoğunu ölüm ile bütünleşen ya da herhangi bir yakınının ölümüyle yalnızlaşan karakterleri ortaya çıkartır. Önce annesini kaybeden İlaman'ın sonra babasını savaşa göndermesiyle ölüm haberini alarak adım adım yalnızlaştığı görülmüş ve İlaman, bu durumu kabullenmiştir. İlaman'ın yalnızlaşma süreci romanın vaka süreci sırasına uygun olarak gelişme gösterir. Ancak Öğretmen Üzümgül'ün İlaman'ın teyzesi olduğu anlaşıldıktan sonra İlaman kendine yer edinir. Önce teyzeye sığınır. Ardından hayatının dönüm noktalarından birini yaşayarak Aşkabat'a yerleşir. Böylece yalnızlık ve yalnızlığın vermiş olduğu ümitsiz ruh halinden sıyrılmış olur.

Romanın sonlarına doğru yalnızlık kavramı olay örgüsüne göre birçok karakter üzerinde somut olarak tezahür etmektedir. Bu duyguyu en çok hisseden karakter Sülgün olmuştur. Eşi ve her iki kızını peşisıra kaybeden Sülgün, ölüm mefhumunu derinden yaşayarak yavaş yavaş yalnızlaşır. Yalnızlığı iliklerine kadar hisseden Sülgün, yalnızlık ile birlikte ruhsal devinimlerle mücadele etmek zorunda kalır.

\subsection{4. Ölüm}

Uzak Uzak Yıllar romanında ağırıklı olarak hissedilen temaların başında ölüm gelir. Bu temanın romanda yoğun olarak hissedilmesinin nedeni roman konusunun savaş olmasından kaynaklanmaktadır. Romanda ölen kişiler ya doğrudan savaşta ölmüşler ya da dolaylı olarak savaşın etkilerine maruz kalarak hayatlarını kaybetmişlerdir. Ölüm teması savaşın bir sonucu olarak ortaya çıkarken bireysel unsurlar üzerinde etkiler bırakmıştır. 
Romanda karakterlerin çoğu savaş sırasında öldürülmüşlerdir. Ancak savaşta ölen kişilerin nasıl öldüğü roman boyunca detaylı olarak anlatılmamıştır. Bu kişiler savaş için cepheye gönderilmiş ve burada ölmüşlerdir. Ölüm haberleri de köydeki yakınlarına iletilmiştir.

Roman karakterleri günlük hayatını sürdürürken ani gelişen olaylar dorultusunda bazı kişilerin ölüm haberiyle sarsılırlar. Tıpkı Kerven Aga'nın savaşta ölmesiyle İlaman için zor günlerin başlaması gibi. Ancak İlaman, romanda metanet ve sabrın bir örneği olarak yaşama karşı direnç gösterir. Üzümgül'ün yardımıyla bu zor durumdan kurtulmaya çalışır.

Ene, Goçaklı'nın savaşa gitmesinden dolayı bir boşluğa düşer. Ancak cinsel eğilimlerini dizginleyemeyen Ene, Akga Brigadir ile yakınlaşmaya başlar. Bir süre sonra yaptığından pişman olur ve ruhsal yetilerini kaybederek ölüm denen nihaî sona doğru ilerler.

Aysoltan, Nursoltan ve Doktur Arzu da savaşın yıkıcı sonuçlarından etkilenen diğer karakterlerdir. Aysoltan ile Nursoltan babaları Muratlı'nın savaşta ölmesinden sonra maddi yetersizlik içinde hayatlarına veda ederler. Doktor Arzu ise oğlunun savaşta ölmesi üzerine dayanamayarak hayata veda eder.

Uzak Uzak Yıllar romanında savaş ve savaşın sonuçlarından etkilenmeyen karakterlerin ölümü de mevcuttur. Bunların başında Durdı Yasavul gelmektedir. Oraz Şıh, maddi çıkarlar için onu öldürmüştür. Durdı Yasavul'un dışında sadece ismi zikredilen kişiler de anlatılmıştır. Bunların ölümü olay örgüsünü geçmiş zamanla ilişkilendirmek ve vak’ayı sürdürmek için anlatılmışlardır.

\section{Sonuç}

Övezdurdu Nepesov, Çağdaş Türkmen Edebiyatı'nın önemli şair ve yazarlarından biridir. Onun bu başarısının ardında yatan temel unsurlardan biri ise tarihin akışı içinde önemli iki ayrı siyasî gelişmeye tanıklık etmesidir. $O$, Türkmenistan'ın Sovyetler'e bağlı olduğu zamalarda edebî çizgisinin temellerini atıp dönemin ediplerini yakından tanıma fırsatı yakalamıştır. Bu dönemde kaleme aldığı eserleri Sosyalist Gerçekçilik anlayışıyla yazmış ve bu doğrultuda edebiyattaki varlığını sürdürmüştür. Nitekim incelediğimiz Uzak Uzak Yıllar romanı da bu nitelikte kaleme alınmış bir eserdir.

Övezdurdu Nepesov'un edebî duyuş anlayışında millet olma şuuru, birlik ve beraberlik intiyacı neticesinde toplumsal olayların çözümlemesi yatmaktadır. Romantizm ile tarih bilimini harmanlayarak itibarî bir eser kurgular. Yazarın Türkmen coğrafyasındaki kültürel ve edebî anlayışını bir nevi yansıtan olay örgüsü, zaman, mekân, tema ve şahıslar ile sağlanan kurgu dürüstlük erdemini ve milli şuuru yakalamaya çalışır.

Roman kurgusundaki izdüşümsel yaklaşımlar sonucunda cereyan eden sosyal hayat, manevî yapı, gelenek ve göreneklerin karakterler üzerindeki çıkarımlarını görmek mümkündür. Romanın tamamına yayılan bu kavramlar ile okuyucu üzerindeki hissettirici etkisi bakımından duygusal ağırlığının yanında toplumsal trajedileri de 
bünyesinde eritmiştir. Böylece karakterler vazifelerine uygun davranarak rollerini başarılı bir şekilde oynamışlardır.

\section{KAYNAKLAR}

Akpınar, Soner 2002, “Yakup Kadri Karaosmanoğlu'nun Romanlarının Yapı ve Muhteva Bakımından İncelenmesi”, Ankara Üniversitesi Sosyal Bilimler Enstitüsü, (Yüksek Lisans Tezi), Ankara

Akpınar, Yavuz- Ağca, Ferruh 2018, Çağdaş Türk Edebiyatları-I, Anadolu Üniversitesi Yayınları, Eskişehir, $245 \mathrm{~s}$.

Aktaş, Şerif 2005, Roman Sanatı ve Roman İncelemesine Giriş, Akçağ Yayınları, Ankara, $144 \mathrm{~s}$.

Boran, Rukiye 2015, “Kemal Abdulla'nın Unutmaya Kimse Yok İsimli Romanı ve Muhteva İncelemesi”, Gazi Üniversitesi Sosyal Bilimler Enstitüsü, (Yüksek Lisans Tezi), Ankara

Buran, Ahmet- Alkaya, Ercan 2001, Çağdaş Türk Lehçeleri, Akçağ Yayınları, Ankara, $347 \mathrm{~s}$.

Buran, Ahmet- Alkaya, Ercan-Yalçın, Süleyman Kaan 2017, Çağdaş Türk Yazı Dilleri1, Akçağ Yayınları, Ankara, 280 s.

Çonoğlu, Salim 2001, Çağdaş Türkmen Edebiyatının Öncü Yazarlarından Annaguli Nurmemmet'in Romanları, Devran Yayınları, Ankara, 535 s.

Deveci, Mutlu 2007, "Anahtar Romanının Yapı ve Tema Bakımından İncelenmesi” ERDEM Insan ve Toplum Bilimleri Dergisi, Sayı:49, s. 77-96

Düz.: Kyýasowa, G.- Geldimyradow, A.- Durdyýew, H. 2015, Türkmen Diliniň Düşündirişli Sözlügi-Iki Tomluk: II Tom. K-Z, Ylym, Aşgabat, 542 s.

Düz:: Kyýasowa, G.- Geldimyradow, A.- Durdyýew, H. 2016, Türkmen Diliniň Düşündirişli Sözlügi-Iki Tomluk: I Tom. A-Ž , Ylym, Aşgabat, 658 s.

Ed. Garrett, Jonathan a.o. 1999, Turkmen-English Dictionary, a SPA project of Peace Corps Turkmenistan, Ashgabat, $160 \mathrm{~s}$.

Eliuz, Ülkü 2014, "Orhan Kemal'in Romanlarında İsim-İçerik İlişkisi”, HECE Aylık Edebiyat Dergisi, Sayı: 205, s. 175-198

Eronat, Kamuran 2010, Adalet Ağaoğlu-İnsan ve Eser, Maya Akademi Yayın Dağıtım Eğitim Danışmanlık, Ankara, $334 \mathrm{~s}$.

Forster, E. M. 2001 Roman Sanatı, (Çev. Ünal Aytür), Milenyum Yayınları, 220 s.

Güldürmez, Sevim 2018, "Savaş ve Edebiyat Araştırmaları", İstanbul Üniversitesi Türk Dili ve Edebiyatı Dergisi, Cilt: 58, Sayı:1, s. 217-227

Hz. Ercilasun, Ahmet Bican v.d. 1992, Karşılaştırmalı Türk Lehçeleri Sözlüğü-1, Kültür Bakanlığı Yayınları, Ankara, $1183 \mathrm{~s}$. 
Hz. Tekin, Talat v.d. 1995, Türkmence Türkçe Sözlük, Simurg Kitabevi, Ankara, 728 s. İpek, İbrahim 2016, “Cumageldi Mülkiyew'in "Selcuklar” Romanı (Aktarma-Muhteva İncelemesi)”, Gazi Üniversitesi Sosyal Bilimler Enstitüsü, (Yüksek Lisans Tezi), Ankara Kaya, Hilal 2012, "Fuzûlî ve John Donne'da Aşk Temasının İşlenişinin Mukayesi", The Journal of Academik Social Science Studies, s. 105-123

Korkmaz, Ramazan 2002, İkaros'un Yeni Yüzü Cahit Sıtkı Tarancı, Akçağ Yayınları, Ankara, $388 \mathrm{~s}$.

Nepesow, Öwezdurdy 1986, Uzak-Uzak Yıllar, Magaryf, Aşgabat,159 s.

Şengül, Mehmet Bakır 2010, "Romanda Mekân Kavramı", Uluslararası Sosyal Araştırmalar Dergisi (The Journal of International Social Research), Volume 3 / 11, s. 528-538

Ünsal, İrfan- Ünsal, Zehra 2014, Türkiye Türkçesi-Türkmen Türkçesi/ Türkmen Türkçesi-Türkiye Türkçesi Sözlük, Liva Yayınevi, Balıkesir, $431 \mathrm{~s}$.

Yalçınkaya, Şerife 2018, “Klasik Türk Edebiyatında Gurbet ve Nevres-i Kadîm'in Gurbeti", Journal of Turkish Language and Literature, Volume: 4, İssue: 1, s. 322-343

Yeğin, Çiğdem 2018, "Çarı Aşırov’un “Göreş” Romanı (Aktarma-Muhteva İncelemesi)", Gazi Üniversitesi Sosyal Bilimler Enstitüsü, (Yüksek Lisans Tezi), Ankara 